\title{
Management of a Karoo fractured-rock aquifer system - Kalkveld Water User Association (WUA)
}

\author{
BH Usher*, JA Pretorius and GJ van Tonder \\ Institute for Groundwater Studies, University of the Free State, PO Box 339, Bloemfontein 9300, South Africa
}

\begin{abstract}
Due to large-scale development of groundwater resources for irrigation purposes the Kalkveld area has been identified by DWAF as an area where a water user association (WUA) should be established in order to achieve better management of the resource. The area represents typical Karoo type fractured-rock aquifers, which consist mainly of sandstone, mudstone, shale and siltstone. The majority of boreholes drilled in Karoo formations have very low immediate yields $(<1 \mathrm{\ell} / \mathrm{s})$. However, large volumes of groundwater are pumped from boreholes in the Kalkveld area for irrigation of commercial crops. Thus, these aquifers have a more complex and unpredictable behaviour than normally described in the literature.

Groundwater management units have been delineated based on: similar hydraulic properties; recharge characteristics; land use; geology (including the distribution of surface calcrete deposits); rainfall; and hydrochemistry. A numerical flow model was constructed for the area to evaluate the impact of increased abstraction on the groundwater resources as well as to evaluate the response of the delineated water management units/areas. To facilitate long-term management of the groundwater resources a user-friendly prediction and management tool was developed. The tool together with the recommended monitoring and management measures should enable DWAF and the WUA to manage the groundwater resource in a sustainable manner.
\end{abstract}

Keywords: groundwater, management tool, Karoo, fractured aquifer

\section{Background}

Due to large-scale development of groundwater resources for irrigation purposes the Kalkveld area has been identified by DWAF as an area where a water user association (WUA) should be established in order to achieve better management of the resource. This process was initiated in 1999 for the Kalkveld area, which consists of the quaternary catchments C52G, C52H, $\mathrm{C} 52 \mathrm{~J}$ and $\mathrm{C} 52 \mathrm{~K}$ and includes the irrigation development areas around Bainsvlei, De Brug and Petrusburg (see Fig. 1). The Kalkveld area falls within Modder and Riet Rivers sub-catchments within the Upper Orange Water Management (UOWMA) area. The four quaternary catchments were grouped together because of similar geology (and geohydrology) and agricultural activities. For administrative management purposes the area was divided into a Petrusburg sub-area $(\mathrm{C} 52 \mathrm{~K})$ and a Bainsvlei sub-area (C52 G, H and J).

The main aim of this project, sponsored by DWAF, was to establish a management and monitoring plan for implementation by the Kalkveld WUA, such that the long-term sustainable use of the groundwater resource would be ensured (Usher et al., 2004).

\section{Description of the study area}

\section{Climate}

The study area has a fairly arid climate with very hot summers and cool to cold winters, and predominantly summer rainfall. Maximum temperatures vary from $31^{\circ} \mathrm{C}$ in summer to $-2^{\circ} \mathrm{C}$ in winter. Average yearly rainfall for the Bloemfontein weather

* To whom all correspondence should be addressed.

욜 +27154012175 ; fax: +27154446538 ;

e-mail: usherb.sci@mail.uovs.ac.za

Received 21 January 2005; accepted in revised form 5 September 2005.

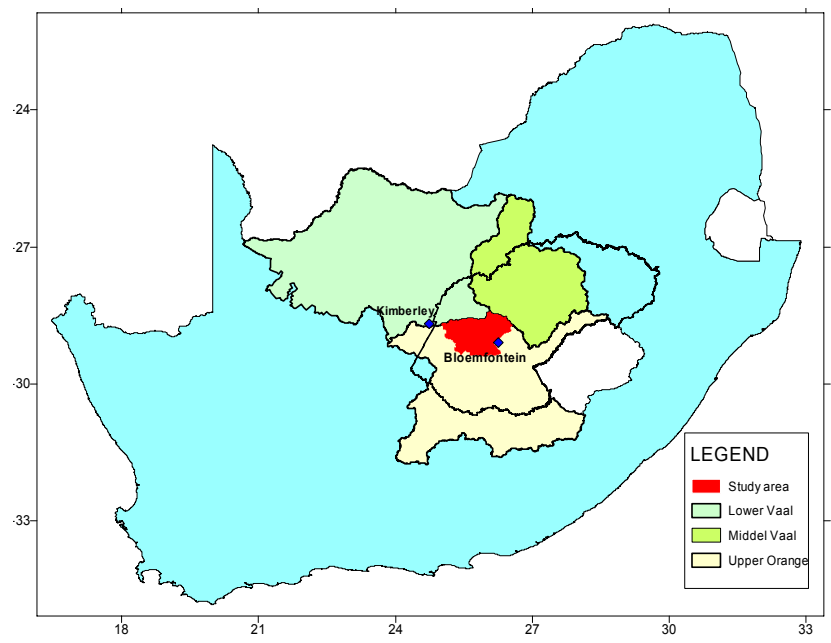

Figure 1

Locality of the study area within the water management areas

station is $559 \mathrm{~mm}$. The study area covers a large geographical area $\left(10700 \mathrm{~km}^{2}\right)$ and rainfall data were obtained from three other weather stations, namely: Petrusburg, Dealesville and Krugersdrift Dam. As part of the monitoring programme in the Petrusburg sub-area, three additional rainfall data-loggers were installed in proximity of the town. A comparison of all rainfall data revealed that there is great spatial variability in rainfall across the area. The highest average annual rainfall is recorded at Bloemfontein $(560 \mathrm{~mm} / \mathrm{a})$ and the lowest annual rainfall at Petrusburg $(390 \mathrm{~mm} / \mathrm{a})$.

\section{Topography and hydrology}

Much of the study area has generally flat to slightly rolling topography, broken only by drainage lines and the occasional 
flat-topped hills or mesas. Natural pan systems, comprising shallow hollows with internal drainage from all sides are characteristic of the area. These represent important ephemeral sources of salty to freshwater during and after the rainy season in otherwise largely semi-arid areas.

The study area includes the quaternary sub-catchments C52K, C52G, C52J and C52H located within the Upper Orange River Catchment (or UOWMA). The main drainage feature in the study area is the westward draining Modder River with the northward draining Klein Modder and Kaal Spruit tributaries. Both these tributaries are non-perennial. Below the Krugersdrift Dam the river flows through a very low gradient terrain where numerous pans are found. The pans are filled at the end of good summer rainfall but seldom overflow (BKS, 2002). Runoff over the investigated area is almost negligible because of the flat topography.

\section{Geology and geohydrology}

The area under investigation is characterised by typical Karoo fractured-rock aquifers, which are the most extensive type of aquifer present in South Africa. The Karoo aquifers occur within the so-called Karoo Supergroup, which consists of different groups of sediments, each with its own physical properties.

A major characteristic of the Karoo Supergroup aquifers, which consist mainly of sandstone, mudstone, shale and siltstone, is their low permeability. The majority of boreholes drilled in Karoo formations therefore have very low yields $(<1 \mathrm{l} / \mathrm{s})$. However, large volumes of groundwater are pumped from wellfields for water supply at towns, mines and from the basements of buildings on a daily basis, in areas underlain by the Karoo formations, which is not what one would expect from aquifers with a limited yield (Woodford and Chevallier, 2002). This is especially true for the Kalkveld area.

Detailed geological assessment of Karoo formations has indicated two very important consequences for the behaviour of Karoo aquifer systems, namely:

- On a regional scale, flow in the Karoo formations largely resembles flow in a porous medium and therefore obeys Darcy's Law

- The formations may contain large quantities of water, but are not able to release it readily over small areas, such as the circumference of a borehole (Woodford and Chevallier, 2002).

The main conclusion drawn is that the behaviour of Karoo fractured aquifers is ultimately determined by their unusual geometry, particularly where horizontal, bedding-parallel fractures are present. These features provide not only the conduits for water to boreholes in Karoo aquifers, but also play a prominent role in the interactions responsible for the behaviour of these aquifers. One very important consequence of these interactions is that flow in Karoo aquifers is not only radial and horizontal, but linear and vertical. This property differs so much from that of the theoretical media usually presented in the literature on aquifer mechanics that the existing conceptual models are useless for the analysis of hydraulic tests performed on Karoo aquifers.

It is generally accepted that boreholes are the most costeffective method of withdrawing water from an aquifer. The dependence of a borehole's yield on the presence and properties of a fracture, however, again raises the question on whether boreholes are actually the best method whereby water should be withdrawn from Karoo aquifers. Botha et al. (1998) concluded that, although some of the negative impacts can be restricted by adopting optimal pumping regimes and correct spacing of production boreholes, it would be more favourable to withdraw water from Karoo fractured aquifers by methods other than boreholes.

The geology of the study area comprises Tierberg shale, Ecca Group and Beaufort Group sandstone and water-bearing features are limited to fractures and changes in lithology. The given yields from these borehole logs are an example only, but do not reflect any specific trends in the aquifer systems.

Actual borehole logs were selected from the NGDB database to give examples of typical geological formations encountered in the study area. Generally the formations encountered are typical shale and sandstone with dolerite intrusions at various depths and thickness. Little or no mention is made of soil profiles and calcrete deposits. In order to describe the role of overburden materials in groundwater occurrence in the study area, more detailed information in this regard will be required. From the data and experience it could, however, be deducted that these boreholes would have average yields between 0.1 to $6 \ell / s$.

\section{Field work}

The project included a fieldwork phase, during which data were collected to fill information gaps identified during the desk top study and previous studies.

\section{Hydro-census}

The hydro-census included the survey of approximately 200 farms/plots distributed throughout the study area and of boundary areas. Data collection was very dependant on the knowledge of the farm owners or occupants.

The 326 boreholes found in the hydro-census provide many data on the water levels in the area. The average water level in the study area is around $12.3 \mathrm{~m}$ below surface level. Only $5 \%$ of boreholes have water levels below $27 \mathrm{mbgl}$ (meters below ground level), while the 25 th and 75 th percentiles fall at 7.4 and $17.9 \mathrm{mbgl}$ respectively. By including the National Groundwater Database (NGDB) (2002) and Petrusburg hydro-census data in the assessment a far better distribution of boreholes is obtained for consideration. Using these additional values, the average water level for the area becomes $11.8 \mathrm{mbgl}$.

The reported abstraction for each borehole is also of interest. It must be emphasised that these values are often "as reported" and that field verification is not possible for all the boreholes. Average discharge measured at boreholes is in the order of $3 \ell / \mathrm{s}$.

\section{Water quality sampling}

A selected subset of these boreholes was sampled for laboratory analysis. On this subset the basic parameters of electrical conductivity as indication of the salinity and $\mathrm{pH}$ was determined in the laboratory. Additionally all these samples were analysed for chloride concentrations $(\mathrm{Cl})$, so that recharge determinations could be done. In the recharge discussion the dangers of using these values for recharge in the Ecca is emphasised. On an even smaller subset, a full macro-analysis of the water was done.

\section{Pumping test analyses}

The three pumping tests that were conducted and the data collected were analysed in conjunction with several previous pumptest data sets. 
For management purposes, the formation T-value is a requirement and the estimation of this T-value is a function of the abstraction rate during the constant rate pumping test. For example, Fig. 2 shows the graphs and T-values obtained for borehole M11 drilled in Tierberg shale along a dolerite dyke on the Meadhurst Test Site in Bainsvlei. The blow yield of the borehole was about $8 \mathrm{l} / \mathrm{s}$ and two constant-rate tests were conducted on this borehole at rates of 3 and $7 \ell / s$.

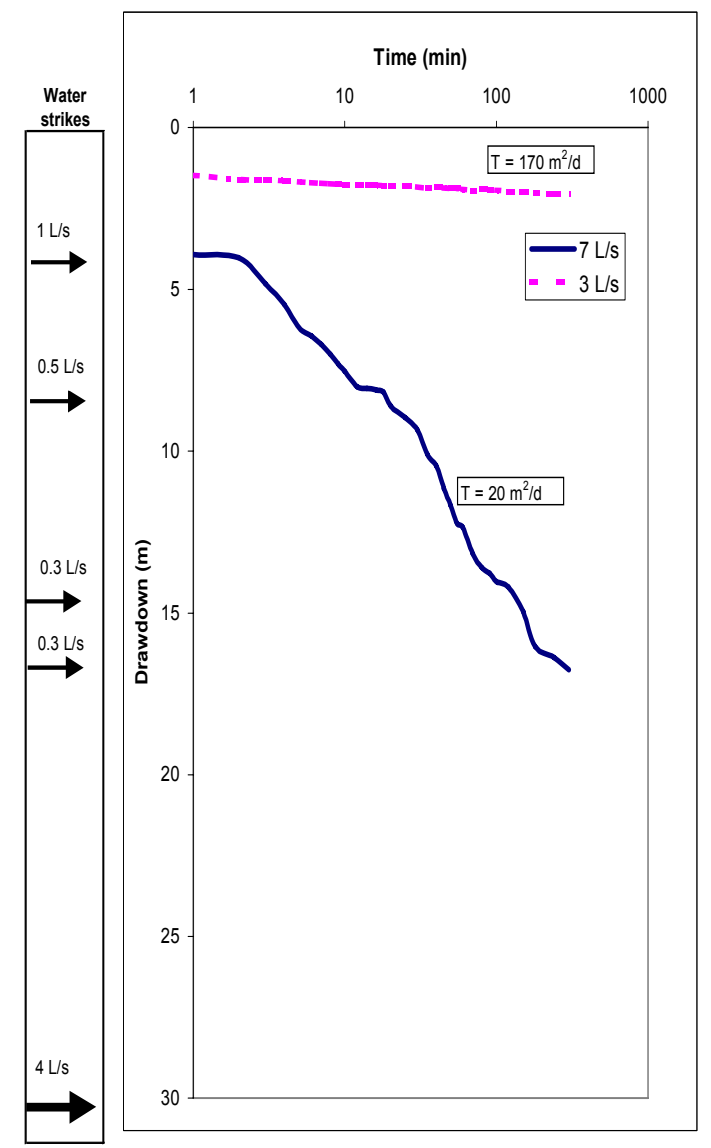

Figure 2

Pumping test results and water strike information of borehole M11 on the Meadhurst test site
It is clear from Fig. 2 that the results from the two abstraction rates produced different drawdown curves. The estimated T-value with the $3 \mathrm{l} / \mathrm{s}$ abstraction rate is $170 \mathrm{~m}^{2} / \mathrm{d}$, while the estimated T-value for the $7 \mathrm{l} / \mathrm{s}$ second abstraction rate is $20 \mathrm{~m}^{2} / \mathrm{d}$. At a rate of $7 \ell / \mathrm{s}$, the fractures could not sustain the abstraction rate with the result that the estimated T-value of $20 \mathrm{~m}^{2} / \mathrm{d}$ is the formation T-value, while the lower rate gives a T-value which is more representative of the fractures. It is of interest to note that a long-duration pumping test performed on borehole M1, which is situated $88 \mathrm{~m}$ from M11 along the same dyke, also gave a formation T-value of $20 \mathrm{~m}^{2} / \mathrm{d}$. Details of pumping tests in the area are given in Table 1.

Using these relationships, and the data collected from the hydro-census and the aquifer tests conducted in this study, correlations between the aquifer parameters and reported blow yields were empirically derived. This allows extrapolation of the results into areas where detailed information is not available and serves as a first step for the delineation of different groundwater zones. This differentiation was used with other information to define groundwater management units for the study area.

Figure 3 shows the correlation between blow yield and fracture + matrix T-value, while Fig. 4 shows the scaled correlation (Meadhurst borehole M11 results were used) between blow yield and formation T-value. Based on these considerations, the proposed equa-

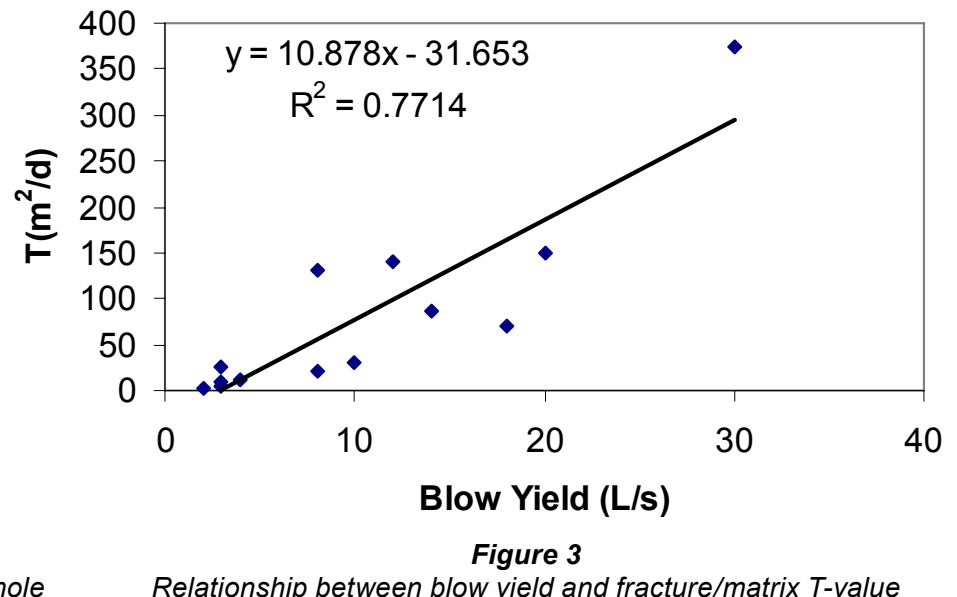

\begin{tabular}{|l|l|c|c|c|c|c|}
\hline \multicolumn{9}{|c|}{ TABLE 1 } \\
\hline & Gumping test results \\
\hline Borehole & $\begin{array}{c}\text { Blow } \\
\text { yield } \\
(\mathbf{\ell} / \mathbf{s})\end{array}$ & $\begin{array}{c}\text { Pump } \\
\text { test rate } \\
(\mathbf{\ell} / \mathbf{s})\end{array}$ & $\mathbf{T}\left(\mathbf{m}^{2} / \mathbf{d}\right)$ & $\begin{array}{c}\text { Formation } \\
\mathbf{T}\left(\mathbf{m}^{2} / \mathbf{d}\right) \\
{[\mathbf{e s t i m a t e}]}\end{array}$ & $\mathbf{S}$ \\
\hline Hopewell & Weathered dolerite/calcrete & 12 & 8.5 & 375 & 70 & 0.01 \\
\hline Arbeid Adelt & Calcrete/mudstone & 20 & 3.2 & 150 & 40 & .007 \\
\hline Graspan & Dyke contact & 12 & 3 & 140 & 30 & .006 \\
\hline Meadhurst M11 & Dyke contact & 8 & 2.86 & 130 & 20 & .006 \\
\hline Meadhurst M11 & Ditto & 8 & 7 & 20 & 20 & .006 \\
\hline Meadhurst M1 & Dyke contact & 3 & 3 & 10 & 10 & .006 \\
\hline Meadhurst M5 & Dyke contact & 2 & 1.8 & 3 & 3 & .006 \\
\hline Putdam & Dyke contact & 18 & 5 & 70 & 37 & .009 \\
\hline Petrusburg: & & 14 & 4 & 87 & 40 & .01 \\
\hline G47346-W of Petrusburg & Dyke contact & 3 & 1.4 & 4 & 4 & .01 \\
\hline G47348- Hartswater & Dyke contact & 3 & 2 & 26 & 10 & .01 \\
\hline G47368-Tafelkop & Dyke contact & 10 & 6.5 & 30 & 22 & .01 \\
\hline G47370-Tafelkop & Dyke + sill & 4 & 4 & 12 & 12 & .01 \\
\hline G47371- Immigrant & Dolerite & & & & & \\
\hline
\end{tabular}


tion to estimate formation T-value if the blow yield is known:

Formation $\mathrm{T}\left[\mathrm{m}^{2} / \mathrm{d}\right]=2.3 *$ Blow yield $[\ell / \mathrm{s}]$

\section{Water quality assessment}

The water quality obtained in this study and previous studies was discussed in broad terms according to variance, adherence to standards and distribution. Overall, the water quality is good, with localised areas of poor water quality (generally associated with elevated $\mathrm{Cl}$ and $\mathrm{Na}$ ) and widespread problems with hardness.

The electrical conductivity is a good indication of the total dissolved salts in the groundwater. From the data obtained, almost all the boreholes fall within the recommended limits for drinking water. The water quality, according to the electrical conductivity as a measure of salinity, is therefore excellent with $89 \%$ of the boreholes having an EC less than $150 \mathrm{mS} / \mathrm{m}$. The EC distribution shows that the majority of values fall in the range of 80 to $120 \mathrm{mS} / \mathrm{m}$. In selected areas, nitrate values exceed the drinking water standards.

\section{Recharge}

The recharge determination is one of the critical aspects of any groundwater management plan. The discussion below outlines the approaches used and give an indication of expected recharge and recharge zonation in the area.

\section{Chloride method}

The harmonic mean of the $\mathrm{Cl}$ concentrations recorded for 23 boreholes spread over the catchment area (excluding boreholes that intersect calcrete), was used as the mean $\mathrm{Cl}$ concentration

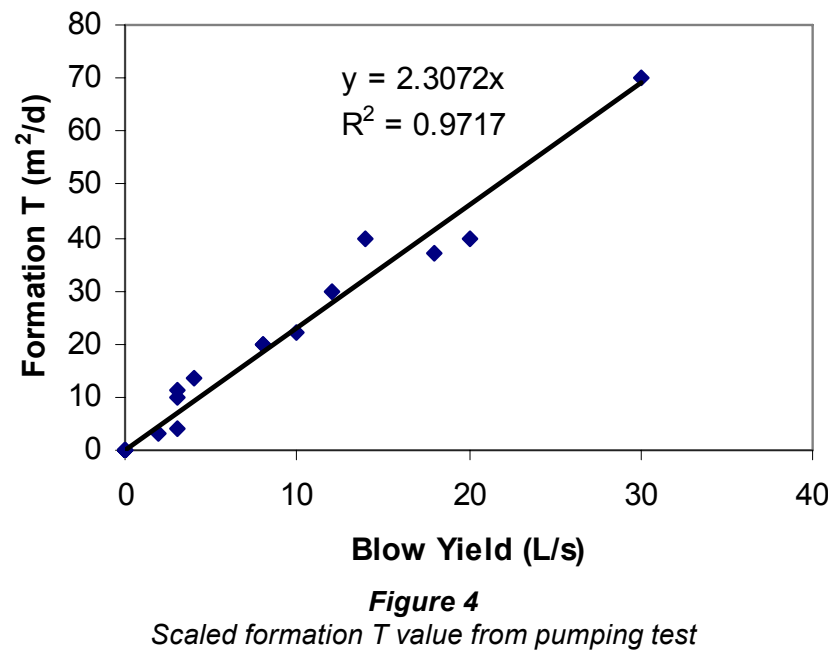

in the groundwater $(40 \mathrm{mg} / \ell \mathrm{Cl})$. A mean $\mathrm{Cl}$ concentration of $0.8 \mathrm{mg} / \ell$ was used for rainwater as measured from 26 rainfall events in Bloemfontein. This implies that on average recharge is about $2 \%$ of MAP. The presence of calcrete and mineralised Ecca shale means that the $\mathrm{Cl}$ method should be used with extreme caution in the study area. Where the geology is sandstone-dominated and where the unsaturated zone is sandy, the $\mathrm{Cl}$ values do provide an indication of the recharge.

The $\mathrm{Cl}$ method was then used for an area known to have no calcrete deposits. Meadhurst borehole M4 was selected and a value of $30 \mathrm{mg} / \ell$ for $\mathrm{Cl}$ was measured in a sample taken just below water level. The recharge $\%$ calculation is thus equal to $1 / 30=3.3 \%$.

\section{SVF-method (Helderwater borehole water level graph)}

This method is based on the saturated water balance, therefore taking into account inflows, outflows, recharge and the change in aquifer storage (saturated volume) over time. The method provides an indication of the water level response of the aquifer and the solution is based on a water balance and storage approach (Bredenkamp et al., 1995). Using this methodology and the data for the Helderwater borehole, the recharge in the vicinity of Helderwater can be estimated as $7 \%$ of MAP.

\section{EARTH model - single borehole}

The Extended Model for Aquifer Recharge and Soil Moisture Transport through the Unsaturated Hardrock (EARTH) method is a lumped parametric model for the estimation of groundwater recharge. This is a complicated model, taking into account precipitation, interception, evaporation, ponding, soil moisture storage, root uptake, percolation, unsaturated flow, recharge, groundwater level fluctuations and drainage. The general equation is given by (Gehrels and Van der Lee, 1997). The data required are monthly rainfall and precipitation, preferably over an extended time period, while the other parameters are generalised from available data.

Data from the six automatic water level recorders installed in the Petrusburg area as well as from the borehole on the farm Helderwater, located just northwest of the town, were used as input to the EARTH model. These results are provided in Table 2.

From the above use of the EARTH method a recharge for this area is estimated at $7.4 \%$ of MAP. Long-term time series data are required across the Kalkveld to quantify the recharge in the area with a high degree of confidence.

\section{Modelling}

In order to investigate an aquifer system in a changing time or space, a numerical groundwater model can be extremely

\begin{tabular}{|l|l|c|c|c|c|}
\hline \multicolumn{7}{|c|}{ TABLE 2 } \\
\hline $\begin{array}{l}\text { Zone } \\
\text { number }\end{array}$ & Name & $\begin{array}{c}\text { Estimated } \\
\text { abstraction } \\
\left(\mathbf{m}^{3}\right)\end{array}$ & $\begin{array}{c}\text { Expected } \\
\text { recharge } \%\end{array}$ & $\begin{array}{c}\text { Recharge } \\
\text { minimum } \\
\%\end{array}$ & $\begin{array}{c}\text { Recharge } \\
\text { maximum } \\
\%\end{array}$ \\
\hline 1 & Dealesville/Boshof & 3643844 & 2.0 & 1.50 & 3.00 \\
\hline 2 & Brandfort/Soutpan & 5969757 & 2.7 & 2.00 & 4.00 \\
\hline 3 & Bainsvlei & 55831533 & 3.4 & 2.50 & 5.50 \\
\hline 4 & De Brug/Hagesdam & 17371892 & 5.1 & 4.00 & 7.00 \\
\hline 5 & Petrusburg & 87814292 & 5.5 & 4.00 & 9.00 \\
\hline
\end{tabular}


Figure 5

Catchment boundaries and management zones with existing and proposed groundwater and water levels) monitoring positions (quality

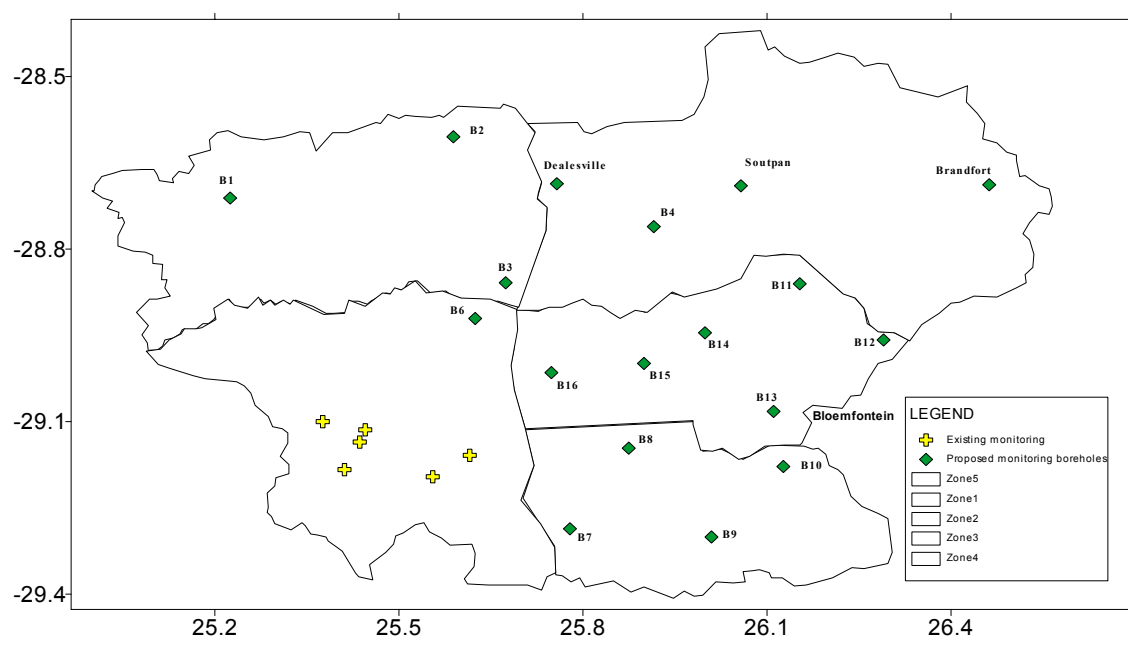

- The groundwater resource is under medium stress and it thus important to follow a very practical and good monitoring plan for the area.

all groundwater models, a representation of the naturally occurring conditions. Certain assumptions therefore had to be made, while certain limitations also persisted in representing natural conditions. The aquifer was modelled on a very large scale as a whole (Rudloph, 2002), but consideration was also given to models completed on smaller scale within the study area.

The conclusions from this work are that smaller-scale models give limited improvement in the overall answers and that numerical modelling should not be attempted on the area until a long-term high quality monitoring record is in place throughout the Kalkveld area. Without this, the results of the numerical modelling exercise will continue to be of limited value, and simpler water-balance approaches will give equivalent or better results.

\section{Reserve determination}

The National Water Act requires that water be allocated to the Ecological Reserve before water is allocated to other users in a particular catchment. It is important to realise Reserve determinations are not intended for individual allocations. Rather, Reserve determinations are conducted for significant water resources. This information is then fed into the catchment management and licensing process, during which individual applications and allocations are considered. It is their task to use the resource quality objectives (RQOs) to develop a water management strategy for a particular resource or to translate that into specific licensing conditions.

The Reserve has been determined for the quaternary catchments C52G, C52H, C52K and C52J (Van Tonder and Rudloph, 2003). When considering reference conditions regarding the groundwater level, the change of land use from natural grassland to mainly cultivated land over the past 50 years, has to be considered. This can be attributed to a change in grass and plant cover as well as increased abstraction for irrigation. An overall lowering of the water table can thus be expected. The following can be deducted from this Reserve determination:

- Except for the riparian vegetation along the Modder River, the influence of groundwater on the flow in the Modder River is for all practical purposes zero.

- The Basic Human Need Reserve of $1.2 \mathrm{Mm}^{3} / \mathrm{a}$, is a maximum as estimated in this study because the maximum potential number of people was used.

- $147 \mathrm{Mm}^{3}$ of groundwater is currently used per annum to irrigate more than 19000 ha.

\section{Delineation of groundwater management units}

Groundwater management units/zones (GMUs) were delineated. Such delineation was based on similar hydraulic properties; recharge characteristics; land use; geology; rainfall; and hydrochemistry. By using a combination of spatial distribution of these parameters and inter-relating these factors, a clearer definition of units/zones was obtained.

The extent of the calcrete is critical and in this regard the chloride/alkalinity ratios were used, since the genesis of the typical Karoo sediments and that of the calcrete differs. This results in a difference between the ratio of the major ions, and in this area, the relative bicarbonate to chloride ratio provided a means to differentiate between different hydrochemical facies, and consequently provided a good starting point to delineate the zones.

Another consideration was the manageability of the zones. Zones need to be large enough to simplify practical management but cannot be too large so that site-specific influences can be considered. Therefore in conjunction with the above factors, boundaries such as quaternary catchments, river systems and farm boundaries were also considered. Using this rationale the zones were selected as shown on Fig. 5.

Using a combination of techniques and statistics the abstraction volume and area under irrigation were estimated for each zone. Data were used from the satellite interpretations of the area irrigated (SAC, 2003) and the WARMS database. It was found that the area irrigated, indicated on the satellite interpretation, was overestimated and the area irrigated from the WARMS database, was an under- estimation. The pivot areas indicated on the satellite interpretation were used in combination with a realistic statistical estimation of the area. It must be noted that it is imperative that the true area under irrigation must be verified through some process acceptable to the WUA and DWAF.

For the volume abstracted the software SAPWAT (WRC, 2003) was used to determine the crop needs for the area. It was assumed that $75 \%$ of the area under irrigation would be used for a summer and winter crop type. The summer crop selected was short-season maize, and the winter crop was short-season wheat. The irrigation need collectively for these two crop cycles was estimated at $1028 \mathrm{~mm} / \mathrm{yr}$. This value was obtained using normal rainfall as input. 


\begin{tabular}{|c|c|c|c|}
\hline \multicolumn{4}{|c|}{$\begin{array}{c}\text { TABLE } 3 \\
\text { Water quantity management parameters }\end{array}$} \\
\hline \multirow[t]{2}{*}{ Zone } & Name & Total Recharge $\left(\mathrm{Mm}^{3} / \mathrm{yr}\right)$ & $\begin{array}{l}\text { Maximum \% of Farm to } \\
\text { Irrigate }\end{array}$ \\
\hline & Parameter from: & $\begin{array}{c}\text { Calculated } \\
\text { recharge values }\end{array}$ & $\begin{array}{l}\text { Recharge and expected } \\
\text { abstraction }\end{array}$ \\
\hline 1 & Dealesville/Boshof & 19620 & $2.7 \%$ \\
\hline 2 & Brandfort/Soutpan & 44875 & $4.3 \%$ \\
\hline 3 & Bainsvlei & 33190 & $6.4 \%$ \\
\hline 4 & De Brug/Hagesdam & 34335 & $7.2 \%$ \\
\hline 5 & Petrusburg & 68585 & $9.5 \%$ \\
\hline \multirow[t]{2}{*}{ Zone } & Name & Max WL drop $(m)^{1}$ & $\begin{array}{l}\text { Maximum Regional } \\
\text { Water Level (mbgl) }\end{array}$ \\
\hline & Parameter from: & $\begin{array}{c}\text { From expected S-value } \\
\text { and time-series water } \\
\text { levels }\end{array}$ & $\begin{array}{l}\text { From Hydrocensus } \\
\text { values }\end{array}$ \\
\hline 1 & Dealesville/Boshof & 5 & 18 \\
\hline 2 & Brandfort/Soutpan & 5 & 35 \\
\hline 3 & Bainsvlei & 4 & 30 \\
\hline 4 & De Brug/Hagesdam & 5 & 25 \\
\hline 5 & Petrusburg & 6 & 25 \\
\hline \multirow[t]{2}{*}{ Zone } & Name & Ideal Water Level (mbgl) & $\begin{array}{l}\text { Max Recommended } \\
\text { Water Level (mbgl) }\end{array}$ \\
\hline & Parameter from: & Hydrocensus values & Hydrocensus values \\
\hline 1 & Dealesville/Boshof & 4 & 12 \\
\hline 2 & Brandfort/Soutpan & 3 & 25 \\
\hline 3 & Bainsvlei & 5 & 25 \\
\hline 4 & De Brug/Hagesdam & 6 & 20 \\
\hline 5 & Petrusburg & 8 & 20 \\
\hline \multicolumn{4}{|c|}{$\begin{array}{l}{ }^{1} \text { This represents the maximum drop in water level from the selected reference level over } \\
\text { time and acts as an immediate flag. } \\
{ }^{2} \text { This is the maximum regional water level, no water levels should be allowed to drop } \\
\text { below this. }\end{array}$} \\
\hline
\end{tabular}

The pertinent statistics for each management zone are given in Table 3.

Using these zones, the models and broad water balances could be calculated and used for determining zone-specific management rules and input parameters. Examples of zonespecific rules include:

- Maximum permissible drawdown (based on current water level records and driven by recharge and the zone's S-value).

- Maximum water level depth.

- Maximum irrigated areal ratio per property size.

\section{Prediction and management tools}

In order to facilitate long-term management of the groundwater resources a user-friendly prediction and management tool has been developed. The prediction tool will be a first-order assessment tool to gauge the impact of changes in water use on the groundwater resource. As such it has incorporated several simplifying assumptions, and should not be seen as a replacement for detailed data collection or assessment through more sophisticated tools. Its greatest advantage will lie in the fact that these tools can be circumvented and that real data will be included on a regular basis.

\section{The Kalkveld Aquifer Management System (KAMS)}

Previously no suitable tool has been developed to manage groundwater on a WUA scale under South African conditions. As such a major focus in this project was the development of a practical user-friendly tool to assist in the sustainable groundwater management. The overall rationale for the tool is provided in Fig. 6.

Once the basic functioning of the tool had been established, the GMUs determined and the management parameters defined, the tool was programmed by AT-Solutions.

\section{Kalkveld groundwater management parameters}

To facilitate practical management, the area was subdivided into zones as discussed above. For each of these zones, management parameters were determined. These parameters form the constraints under which the system should be maintained to ensure sustainable groundwater use in the area (Table 3 ).

It must be emphasised that although these parameters have been carefully selected based on the current data sets, future monitoring is of key importance to update these with a higher degree of confidence than can be done with the current limited data sets. The success of the long-term sustainable management is dependent on the robustness of these parameters and 


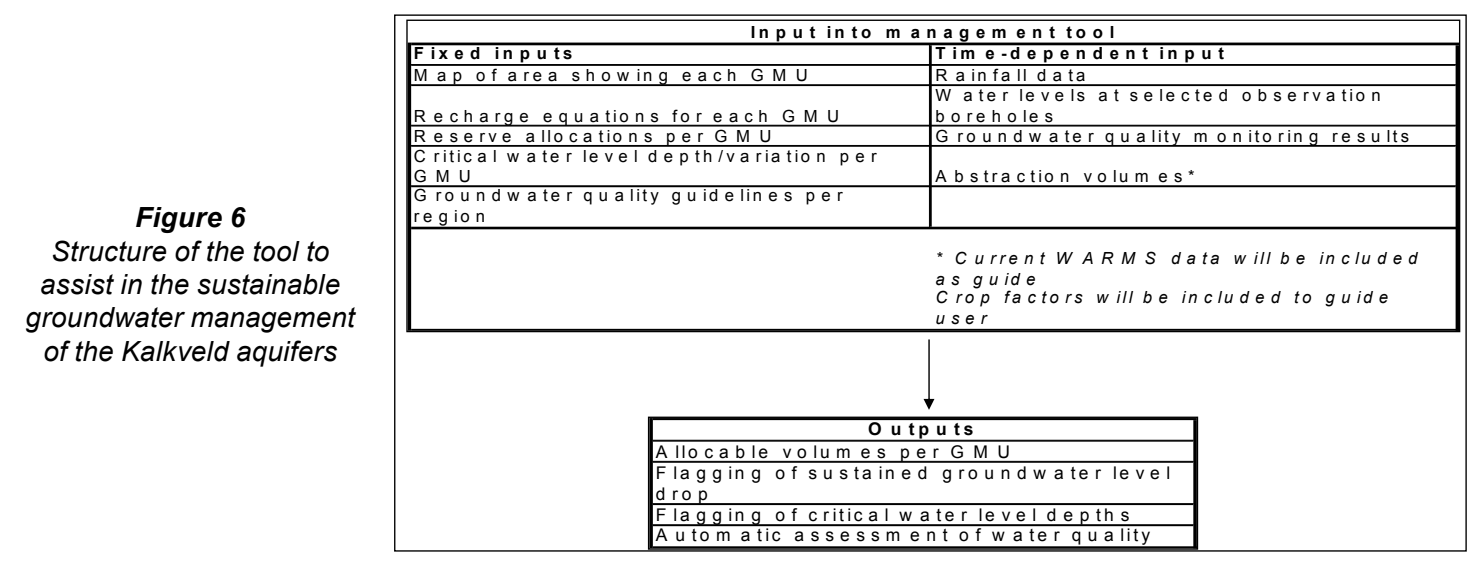

the monitoring data sets are paramount to the veracity of these values.

It should be noted that in some areas the volume for irrigation is somewhat higher than the expected total recharge over the farm area. However, not all the land can be used for irrigation and recharge that occurs in such areas is available for abstraction from the aquifer. In high rainfall years that occur periodically, proportionally higher recharge through episodic recharge events also occurs to replenish the system (Bean, 2004). The role of a management plan would include ensuring that the aquifer is not exploited beyond the point where this periodic replenishment restores the available groundwater resource.

It is acknowledged that in certain areas current water use exceeds the recommended areas of irrigation. The values above represent a short-term (until monitoring data have established the aquifer response over time) indication of areas where the resource should be able to be abstracted without any further conditions to adhere to. Where the values are exceeded by a user the onus must shift to the user to prove that he has no effect on the closest adjacent groundwater user in terms of water levels or quality.

There are certain areas where these values are currently being exceeded by clusters of adjacent users. An example is the 4.28 ha plots in Bainsvlei where $25 \%$ or more of the plot is irrigated for gardens, vegetables or small-scale cultivation. These are the areas where records show persistent decline in water levels, indicating that the aquifer cannot sustain such abstraction. In the interim, it will be difficult to prohibit these activities but as a matter of priority, water level recorders should be installed at monitoring boreholes within these areas. These will provide the data required to justify the limitation of these abstractions, if required.

Using the water quality statistics for each zone as determined by the hydro-census and other available data and importantly drinking water standards and water classes, the water quality parameters have also been established. The parameters should serve to protect the resource and water users while not inhibiting generally acceptable water use practices.

The selected parameters should be used as guidance by the WUA/DWAF, but local discretion, as allowed by the Water Act should also be implemented.

\section{Design and functioning of the KAMS water manage- ment tool}

This tool includes a data interface and incorporates the rainfall, water level, abstraction and water quality data.

The tool combines the detailed findings of this project with spatial capabilities and expert inputs. The user will select the features he wishes to view and have information on, including the GMUs; farm boundaries; rivers; weather stations; boreholes; and irrigation area.

There are three levels of user allowed in the tool namely:

- A viewer (for example a farmer in the area) who can view different aspects of the area such as the borehole data, allocated volumes, and other indicators.

- An administrator who can view and input data.

- A developer who has access to the management parameters and can alter these as more data are collected.

This tool will enable the WUA to manage the resource in a sustainable manner using input from the database created as well as the data collected on an ongoing basis from the monitoring network.

Depending on the level selected the relevant details for the zone can be accessed. If the farm's layer is activated the zone's aspects are viewed together with the allocable volumes for the farm that have been selected (either by clicking on the farm or by selecting the farm through a query). Indicator dials are used throughout the KAMS tool indicating the data in any area selected as shown by Fig. 7 .

KAMS has been written in such a way that selection of the nearest monitoring borehole of the weather station is obtained through an automatic search function. When the user clicks on the area the nearest observation points data will be shown as follows:

- Using this approach an early warning system for each of the key parameters can be established. The indicator shows the whereabouts in the defined management parameters where the borehole currently lies. By clicking on each dial the data set can be seen to ascertain whether there is an increasing or decreasing trend.

- The administrator will be able to change the defined management parameters for each zone within the tool, once further data have been collected and interpreted

- Data input can be achieved by uploading data or by manually adding rainfall or borehole-related data. A filter function has been built in to view only the borehole or weather station's data of interest to the user or viewer.

- Using all of these considerations, when the boreholes are selected, colour coding will provide an instant indication of the compliance of a borehole

\section{Monitoring network}

The sustainable use of groundwater in the area will be determined by correctly and actively managing the resource. This implies 


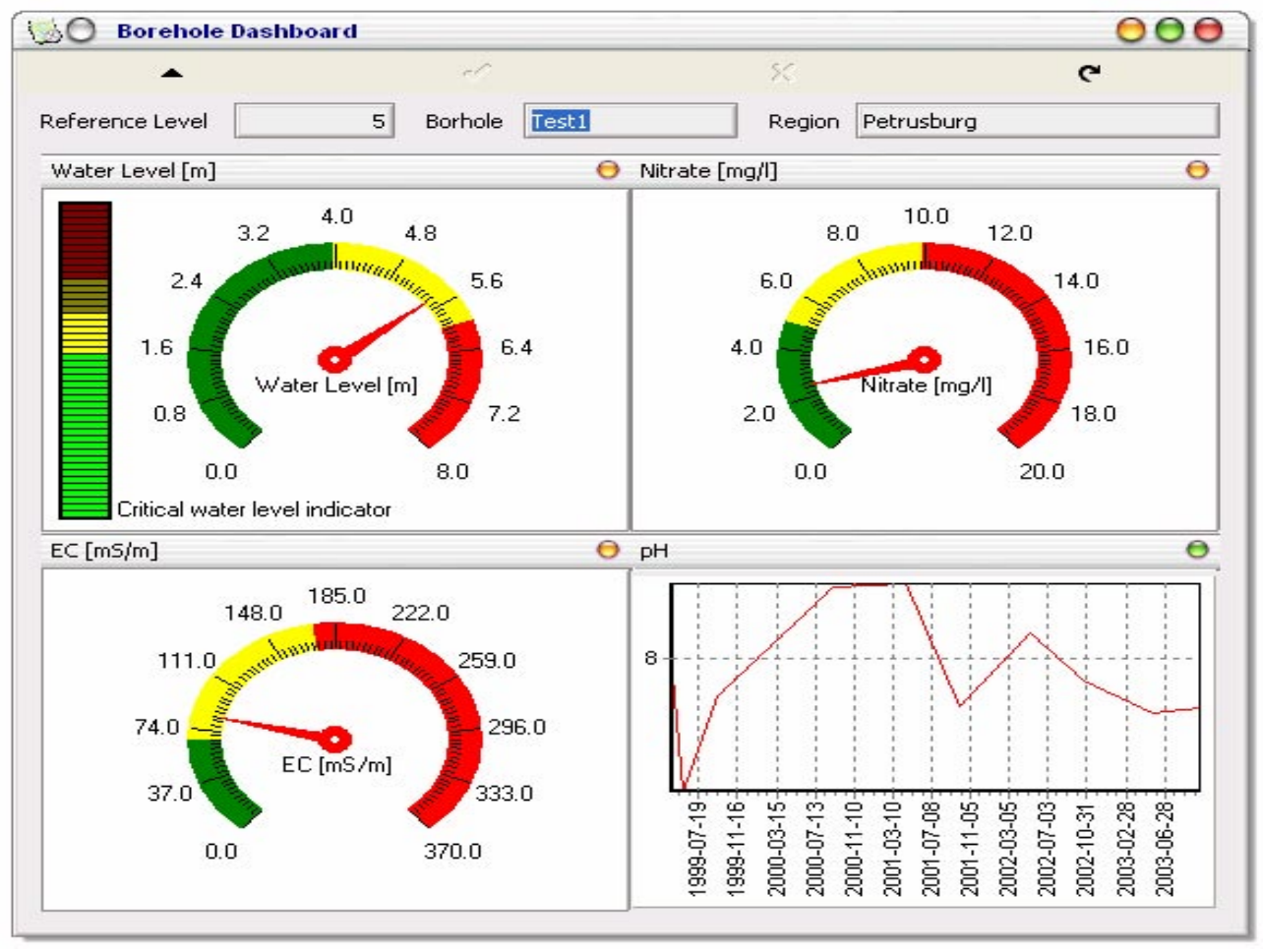

Figure7

Borehole dashboard in the tool that changing conditions such as rainfall variation changes in land-use, regulation etc need to be considered. Through regular monitoring of water levels and water quality, an adequate data set of the hydrogeological system's response can be obtained. Changes in water levels or quality can therefore timeously be detected and appropriate actions implemented.

The existing monitoring network was evaluated and new monitoring points recommended (Fig. 7). The monitoring plan should ideally also include monitoring of irrigation method, areas and crops to be irrigated, and an irrigation schedule for each individual farm.

\section{Evaluation of the existing monitoring network}

For the Kalkveld Groundwater Management Area the existing groundwater monitoring network was only focused on one particular problem area (the town of Petrusburg) and the design thereof thus only reflected the need to protect a particular aspect of the resource. Initially only three automatic water level recorders were installed in three boreholes closest to the well fields and another three recorders followed in areas of high intensity irrigation further away from the town. Additional to the water-level recorders three automatic rainfall recorders were also installed at other strategic positions within the Petrusburg district. The water-level recorders record the water level on an hourly basis.

The data collected on the water-level recorders proved to be very valuable in course of evaluating the response of the aquifer system in the area that is monitored. Due to equipment failures, there are some data gaps in the time series. All of the boreholes show seasonal variations depending on rainfall and irrigation trends. These variations differ depending on the proximity of the boreholes to recharge zones and large-scale abstraction.

There is no current water quality monitoring of groundwater implemented in the study area. During previous and the current investigations several samples were taken and analysed for but no time series data exist for the study area. Some individual users do take samples for own use, but these data are very scarce and not readily available for input into a database.

\section{Recommendations for a new monitoring network}

The existing groundwater monitoring network is inadequate in the greater part of the study area. As discussed above the only area that is monitored is the Petrusburg sub-area. It is recommended that the monitoring network be established with assistance of DWAF and that thereafter the network has to become the responsibility of the WUA. It is further recommended that three levels of monitoring intensity be established:

Level 1 monitoring would entail monitoring of the aquifer on a regional scale as part of the auditing and overseeing function of the Department of Water Affairs. These points should be monitored by DWAF after handover of the greater network to the WUA, in order to assess the management of the aquifer system by the WUA. These points should include at least one water level and water quality monitoring point within each management zone.

Level 2 monitoring will entail the monitoring of the aquifer response within each management zone, and will be the responsibility of the WUA. The proposed monitoring positions are shown in Fig. 7. The number and location of points selected were determined according to the water use and land use in each management zone. This should, however, be re-evaluated yearly and adapted if the need arises.

Level 3 monitoring will entail monitoring on a farm or irrigation development scale. This type of monitoring will be the responsibility of the individual water users, either as part of licence requirements or self-regulating management of the resource. This type of monitoring will not entail the type of detail required by the Level 2 monitoring, but water levels and quality will have 


\begin{tabular}{|c|c|c|c|c|}
\hline \multicolumn{5}{|c|}{$\begin{array}{c}\text { TABLE } 4 \\
\text { Proposed locations installation of automatic water level recorders }\end{array}$} \\
\hline $\begin{array}{l}\text { Management } \\
\text { zone }\end{array}$ & Number & \begin{tabular}{|c|} 
Water \\
quality \\
monitoring \\
point
\end{tabular} & \begin{tabular}{|c|} 
Rainfall \\
monitoring \\
point
\end{tabular} & Description \\
\hline \multirow[t]{3}{*}{ Zonel } & $\mathrm{B} 1$ & & Yes & Central western portion - where main activity is game farming \\
\hline & $\mathrm{B} 2$ & & & North-eastern corner of zone \\
\hline & B3 & & & South-eastern corner of zone \\
\hline \multirow[t]{4}{*}{ Zone2 } & Dealesville & Yes & & Near Dealesville's production boreholes \\
\hline & B4 & & & Central eastern side of zone \\
\hline & Soutpan & Yes & & Near Soutpan's production boreholes \\
\hline & Brandfort & Yes & Yes & Near Brandfort's production boreholes \\
\hline \multirow[t]{6}{*}{ Zone3 } & B11 & & & $\begin{array}{l}\text { North eastern side of zone, irrigation development next to Bultfontein } \\
\text { road. }\end{array}$ \\
\hline & $\mathrm{B} 12$ & & & Eastern part of zone, less irrigation more livestock farming \\
\hline & B13 & & & Bainsvlei small holdings - large-scale irrigation intensity high \\
\hline & B14 & & & Northern central portion of zone - large-scale irrigation intensity high \\
\hline & B15 & & Yes & Central portion of zone - large-scale irrigation intensity high \\
\hline & B16 & & & Western portion of zone - scattered large-scale irrigation \\
\hline \multirow[t]{4}{*}{ Zone4 } & B7 & & & South-eastern corner of zone \\
\hline & B8 & & & $\begin{array}{l}\text { Northern portion of zone - no irrigation, owned by National Defence } \\
\text { Force. }\end{array}$ \\
\hline & B9 & & Yes & Central part of zone - scattered large-scale irrigation \\
\hline & B10 & & & $\begin{array}{l}\text { Next to the Jagersfontein road near the irrigation development on these } \\
\text { small holdings and farms }\end{array}$ \\
\hline \multirow[t]{6}{*}{ Zone 5} & B6 & & Yes & $\begin{array}{l}\text { North eastern corner of the management zone next to the Petrusburg- } \\
\text { Krugersdrift Dam road. }\end{array}$ \\
\hline & B147554 & & & Existing monitoring point \\
\hline & G47101 & & & Existing monitoring point \\
\hline & G47103 & Yes & Yes & Existing monitoring point (in well field of town) \\
\hline & B147520 & & Yes & Existing monitoring point \\
\hline & G47353 & & Yes & Existing monitoring point \\
\hline
\end{tabular}

to be measured at regular intervals and reporting to the WUA and/or DWAF will be required in some instances.

Once the monitoring network is established, it is important that DWAF and the WUA ensure that the data collected are updated and evaluated on a regular basis by a qualified person. Dissemination of information regarding the status of the aquifer should be available at any given time to members of the WUA or any other water users.

\section{Water quantity monitoring}

Regional precipitation variability affects irrigation water demand on an aquifer system, recharge to the aquifer, and the extent to which the aquifer can be used for agricultural irrigation and for municipal, industrial, and domestic water supplies. All these factors affect water withdrawals from an aquifer. Therefore, knowledge of the precipitation variability and its relationship to groundwater recharge over an extensively irrigated region, such as the Kalkveld, should provide useful information for the management of groundwater resources in that region. The objective of rainfall monitoring is to conduct long-term monitoring of precipitation and alongside groundwater levels, to learn how the groundwater resources respond to drought and seasonal irrigation pumping, and to ascertain the temporal recharge intervals due to seasonal pumping. The need for more intensive rainfall monitoring, which is coupled with water-level fluctuations, has therefore been identified.

Figure 5 and Table 4 show the locations and details of the suggested rainfall monitoring points. The monitoring points should ideally be equipped in a similar way to the existing three rainfall recorder points in Petrusburg, and furthermore be located in close proximity to a water-level monitoring point.

As discussed water quantity monitoring entails recording water-level fluctuations, borehole abstractions, and rainfall data. It is suggested that automatic water-level recorders be installed at the locations given in Table 4.

The locations described are only approximations of where water-level monitoring is required. The sites were selected based on the following criteria:

- Spatial distribution throughout zone

- Proximity of large-scale abstraction of groundwater for town supply

- Proximity to high intensity large-scale irrigation.

It is suggested that at least 6 recorders be installed in Zone 3 (Bainsvlei). The area has a high intensity of large-scale irrigation development and is the most likely to be affected in the long term by water-level fluctuations.

Position B8 should be, if possible, located within the Defence Force grounds at De Brug. This area represents a "buffer" zone between the high intensity irrigation of Bainsvlei and Zone 4 . 
The only groundwater use in this area is scattered watering points for game.

A monitoring point should also be installed at each of the towns in the study area. Although groundwater is not the only water supply of all of these towns it is important to protect and manage the resource for possible future growth of the towns. In Dealesville, for example, groundwater for the town's water supply is already cause for concern, with the municipality already experiencing problems with providing sufficient groundwater supply to the town.

The water-level recorders should be installed to measure water-level fluctuations on an hourly basis. This is required so that the response per rainfall event can be studied. Little is known on the response times to rainfall events, and an understanding of the aquifer behaviour will provide inputs towards more accurate recharge determinations and management parameters on a more local scale. Irrigation (or high abstraction) effects may be masked if measurements are only taken once a day if the time of measurement does not correspond to the high abstraction event. The boreholes that are used should be dedicated monitoring boreholes, which are secured against theft and vandalism Ideally the boreholes should be drilled for this purpose and accurate geological logs must be available for the boreholes. Before installation of the recorders the aquifer parameters should be determined for each borehole through aquifer testing.

The data collected at all recorders must be used as input to the management tool (KAMS) developed in this project.

Monitoring of groundwater abstraction volumes on such a large scale is a difficult and costly task. It is, however, possible should the water use in the area be managed through compulsory licensing, that the recording and dissemination of such information becomes the licence holder's responsibility. It is therefore suggested that the licence conditions require that abstraction volume, irrigation methods, area under irrigation, crops to be irrigated, and an irrigation schedule for each individual farm, be reported to DWAF on a twice-yearly basis. The licence conditions could also require, if deemed necessary, that individual users monitor water levels in production or observation boreholes on private properties (Level 3). This will provide valuable information with regard to aquifer response to abstraction and irrigation trends over time, on a more intensive scale than the regional monitoring network.

\section{Water quality monitoring}

Water quality monitoring is the most effective way to ensure the fitness of use of the groundwater resource for the intended use(s). Regular water quality monitoring of indicator components of a water resource will give an early warning if water quality is deteriorating over time.

As discussed, the groundwater quality is generally good in the study area, apart from a few exceptions related to the mineralogy of the sediments. The main use(s) of the groundwater in the study area is for human consumption, stock watering and irrigation.

For the monitoring network it is suggested that only indicator species be analysed for on regular monthly intervals for the first two years. Thereafter, depending on the results, the intervals can be extended. Together with the indicator analyses a twice-yearly full macro element analyses is also recommended at all the monitoring boreholes

Indicator analyses should include electrical conductivity (EC), $\mathrm{pH}$ and nitrate. EC is a measurement of the salinity, $\mathrm{pH}$ would indicate any changes in the system and nitrate would indicate either pollution from on-site sanitation or intensive crop cultivation with irrigation. At boreholes in close proximity of the town's wellfields it is suggested that with the twice-yearly full analyses, microbial analyses for E.coli and faecal coliforms be included.

The samples can be taken at existing boreholes close to the water-level monitoring boreholes and if no equipped borehole is available a dedicated monitoring borehole must be drilled. All boreholes should be purged according to DWAF protocols prior to any sample-taking.

All data must be disseminated to the WUA and/or DWAF on a regular basis and where required used as input to the management tool.

\section{Recommended management options}

After considering all the data and the information collected during this project it is recommended that the following steps be taken to manage the groundwater use in the Kalkveld area.

\section{Compulsory licensing}

Results from this study, and others done in the area, suggest that there is a large variance in the upper and lower estimates of total groundwater abstraction. In order to remedy the situation and gain an understanding of the impact of the abstraction on the resource, verification of the water use in the study area is urgently needed. This verification of registered users will, however, be a very costly and time-consuming process. The disadvantage of such a process will also be that there will still be no effective way to manage and regulate unlawful water users. It is therefore suggested that DWAF in conjunction with the WUA declare the Kalkveld area as an area where compulsory licensing has to take place. The Kalkveld area meets all the requirements for compulsory licensing as set out in Section 43 of the NWA.

Conditions of the licences should be in line with the objectives of the NWA and strictly adhered to. Licences must be revoked with immediate effect if a licensee is in non-compliance of conditions of his/her licence. They can be reissued as soon as compliance is shown

\section{Implementation of dedicated groundwater monitoring system}

The monitoring plan is the cornerstone of entire process in the short term. As such implementation of the monitoring plan is a matter of priority. It is therefore strongly recommended that the proposed monitoring plan be implemented in a short space of time as this will provide the required data to substantiate the management parameters and serve as hard evidence to defuse conflicts within the Kalkveld region (Table 4)

\section{Collection of additional geological data}

This study has identified a number of data and information gaps. One of these is the structural geological framework. The area is characterised by the occurrence of many dolerite dykes and sills that are conducive to the development of fractured aquifers in the surrounding sediments. Many of the boreholes are sited on dolerite intrusions. The other one is the scarcity of data on quaternary geological deposits. The quaternary deposits such as the calcretes play an important role in the behaviour of the groundwater regime. Factors such as recharge, storage and water qual- 
ity are strongly influenced by the presences of these deposits. It is therefore important that more detail on these deposits be collected in the form of maps.

\section{Refinement of management zones}

It must be re-emphasised that due to the paucity of time-series data, uncertainties with current parameters are unavoidable. The implementation of the monitoring system will allow these zones, and the parameters by which they are managed, to be updated and refined, if necessary.

\section{Stakeholder participation}

The process of establishment of the Kalkveld WUA has undergone the required stakeholder participation up to date. As part of this ongoing process, the management zones and parameters and recommendations, e.g. compulsory licensing, should be publicly work-shopped with the stakeholders.

\section{Acknowledgements}

This work was undertaken as a project for Department of Water Affairs and Forestry (DWAF) Free State Region, and the funding of the project by DWAF is gratefully acknowledged. Dr Johan van der Merwe (Project Manager) and Ms Sonia Veltman of DWAF are thanked for their contributions in terms of data and other information towards the project. Rainier Dennis from AT-Solutions is thanked for his assistance in producing a user-friendly application for the concept.

\section{References}

BEAN JA (2004) A Critical Review of Recharge Estimation Methods Used in Southern Africa. Unpublished Ph.D. thesis, University of the Free State, Bloemfontein.

BKS (2002) Catchment Management Strategy for the Modder and Riet Rivers - Water Quality Assessment Report. Unpublished (progress) report prepared for DWAF Free State Region, June 2002.

BOTHA JF, VERWEY JP, VAN DER VOORT I, VIVIER JJP, COLLISTON WP and LOOCK JC (1998) Karoo Aquifers. Their Geology, Geometry and Physical Behaviour. Water Research Commission, Pretoria, South Africa. WRC Report No 487/1/98.

BREDENKAMP DB, BOTHA LJ, VAN TONDER GJ and VAN RENSBURG HJ (1995) Manual on Quantitative Estimation of Groundwater Recharge and Aquifer Storativity. Water Research Commission, Pretoria, South Africa. WRC Report No. TT 73/95.

GEHRELS JC and VAN DER LEE J (1997) Modeling of a fractured dolomite aquifer under semi-arid conditions. In: Simmers I (ed.) Recharge of Phreatic Aquifers in Semi-arid Regions. UNESCO/ IAH Int. Contribution to Hydrogeol. Vol 19. Balkema, Rotterdam.

NATIONAL GROUNDWATER DATABASE (2002) Data received from Department of Water Affairs and Forestry.

RUDOLPH DC (2002) Petrusburg Aquifer Delineation Study. Unpublished report prepared by Geo-Hydro Technologies for DWAF, Free State Region, December 2002.

SATELLITE APPLICATIONS CENTRE (2002) Bainsvlei and Petrusburg Resource Assessment - Uses and Users. Report prepared for DWAF Free State Region.

USHER BH, PRETORIUS JA and VAN TONDER GJ (2004) Establishment of a Groundwater Management Plan for Kalkveld. Unpublished report prepared for DWAF, Free State Region, September 2004.

VAN TONDER GJ and RUDOLPH DC (2003) Rapid determination of the groundwater component of the reserve for Bainsvlei SubArea Quaternary Catchments C52G, C52H and C52J). Unpublished report prepared for DWAF, Free State Region, February 2003.

WOODFORD AC and CHEVALLIER L (2002) Hydrogeology of the Main Karoo Basin: Current Knowledge and Future Research Needs. Water Research Commission, Pretoria, South Africa. WRC Report No TT 179/02. 466 pp.

WRC (2003) SAPWAT Version 2.6.0 available at www.sapwat.org.za. 